\title{
PLASMA PROLACTIN, PROGESTERONE AND OESTRADIOL-17 $\beta$ CONCENTRATIONS AROUND PARTURITION IN THE PIG
}

\author{
M. TAVERNE, A.H. WILLEMSE, S.J. DIELEMAN and M. BEVERS \\ Clinic of Veterinary Obstetrics, A.I. and Reproduction, State University of Utrecht, \\ Yalelaan 7, Utrecht (The Netherlands)
}

(Accepted 8 January 1979)

\begin{abstract}
Taverne, M., Willemse, A.H., Dieleman, S.J. and Bevers, M., 1978/1979. Plasma prolactin, progesterone and oestradiol-17$\beta$ concentrations around parturition in the pig.

Anim. Reprod. Sci., 1: 257-263.

Plasma concentrations of prolactin, progesterone and oestradiol-17 $\beta$ were measured by radioimmunoassay in samples taken from $2-15$ days before until $1-4$ days after spontaneous parturition in four sows and in one sow around prostaglandin F $2 \alpha-$ induced parturition.

Between Days -15 and -2 (Day $0=$ parturition), prolactin concentrations in daily samples fluctuated somewhat, but exceeded $10 \mathrm{ng} / \mathrm{ml}$ only exceptionally. Plasma progesterone levels gradually declined or remained high until about 2 days before parturition. A final decrease of the progesterone concentrations coincided with distinct increases of the prolactin levels during the last $40 \mathrm{~h}$ of pregnancy.

Maximal prolactin concentrations were measured before the onset of delivery of the piglets. Oestradiol-17 $\beta$ reached peak values around delivery. Prostaglandin F $2 \alpha$ injection caused an immediate sharp increase of the prolactin concentration which lasted for about $6 \mathrm{~h}$. During this period progesterone and oestradiol-17 $\beta$ concentrations did not change. A second elevation of prolactin levels was measured when progesterone finally decreased.

Changes of prolactin concentrations found in this study were compared with those found in other domestic animals at the same reproductive stage.
\end{abstract}

\section{INTRODUCTION}

A distinct increase in peripheral biood concentrations of prolactin has been reported in relation to parturition in large domestic animals such as the cow (Hoffmann et al., 1973; Karg and Schams, 1974), sheep (Chamley et al., 1973; Kann and Denamur, 1974) and goat (Hart, 1972).

Apart from the data of Threlfall et al. (1974), who found no significant differences in circulating prolactin values between virgin gilts and sow at either mid-gestation or Day 112 of pregnancy, prolactin concentrations in serially collected blood samples from sows before parturition have not been reported previously. 
Recently Van Landeghem and Van de Wiel (1978), using a heterologous radioimmunoassy, measured high plasma prolactin concentrations at parturition in one sow.

This study describes plasma concentrations of prolactin, progesterone and oestradiol-17 $\beta$, as determined by radioimmunoassay, in four sows during the last $2-15$ days of pregnancy and spontaneous parturition. In one sow hormone values were established around a prostaglandin-induced parturition.

\section{MATERIAL AND METHODS}

Of the five gilts used in this study, four were minipigs (nos. IV, V, VIII, XI) from the stock of the Zoötechnical Institute (State University of Utrecht, The Netherlands). Animals from this stock were from the original Gottinger strain but have been crossed several times with Dutch Landrace pigs. The other gilt (no. 2.78) was a cross of these last two breeds.

Between Days 88 and 105 of pregnancy (Day 0 is the day of mating), a silastic indwelling catheter was implanted in the anterior vena cava (technique described by Ellendorff et al., 1977). A laparotomy was performed in four gilts in order to mark the fetuses. Surgical details and results of these intra-uterine fetal marking experiments have already been published (Taverne et al., 1977). After the operation the animals were placed in individual pens and received antibiotics for 4 days.

Blood samples of $10 \mathrm{ml}$ were taken daily in all animals; data presented are from $2-15$ days prior to parturition until $1-4$ days afterwards. The frequency of bloodsampling was increased in three animals at impending parturition. One sow (no. XI) was injected intramuscularly with $10 \mathrm{mg}$ prostaglandin F2 $\alpha$ (Dinoprost, Upjohn Company, Kalamazoo, Mich., U.S.A.) on Day 110 of pregnancy. After injection frequent blood sampling took place until parturition was completed. The blood was centrifuged at $4^{\circ} \mathrm{C}$ and the plasma was stored at $-20^{\circ} \mathrm{C}$ until required for assaying. Concentrations of prolactin (PRL), oestradiol-17 $\beta$ (E2 $\beta$ ) and progesterone (P4) were determined by radioimmunoassay as described by Bevers et al. (1978), Bontekoe et al. (1977) and De Jong et al. (1974), respectively.

\section{RESULTS}

Spontaneous parturition took place in sow no. V (Day 113; seven piglets), no. VIII (Day 110; seven piglets), no. 2.78 (Day 114; four piglets) and no. IV (day of pregnancy not known; seven piglets).

Plasma P4, E2 $\beta$ and PRL concentrations in daily samples from these four animals are presented in Fig. 1. Plasma prolactin values fluctuated between Day -15 and Day -2 (Day $0=$ parturition) but levels remained below $10 \mathrm{ng} /$ $\mathrm{ml}$ with only a few exceptions. In two sows (nos. V and XI) a small but steady increase was measured. Progesterone levels either gradually decreased during the last 2 weeks of pregnancy (nos. $\mathrm{V}$ and 2.78) or did not obviously 

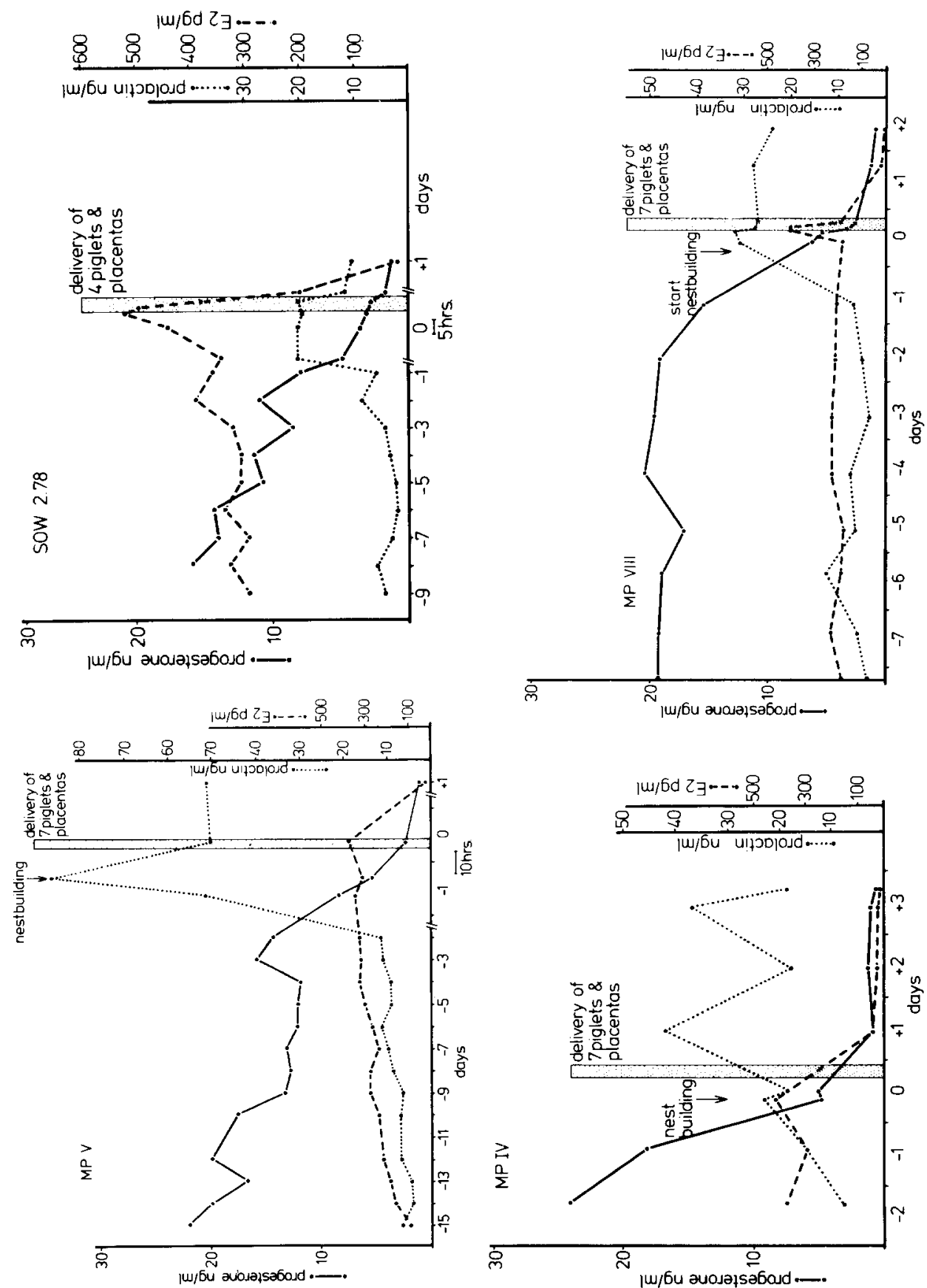

象

응 능

马

ธี

के

혈

혁

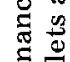

क्.

ㄹ.

合

正

so

.

כี

दे

옥

焉

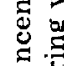

용

है

苟

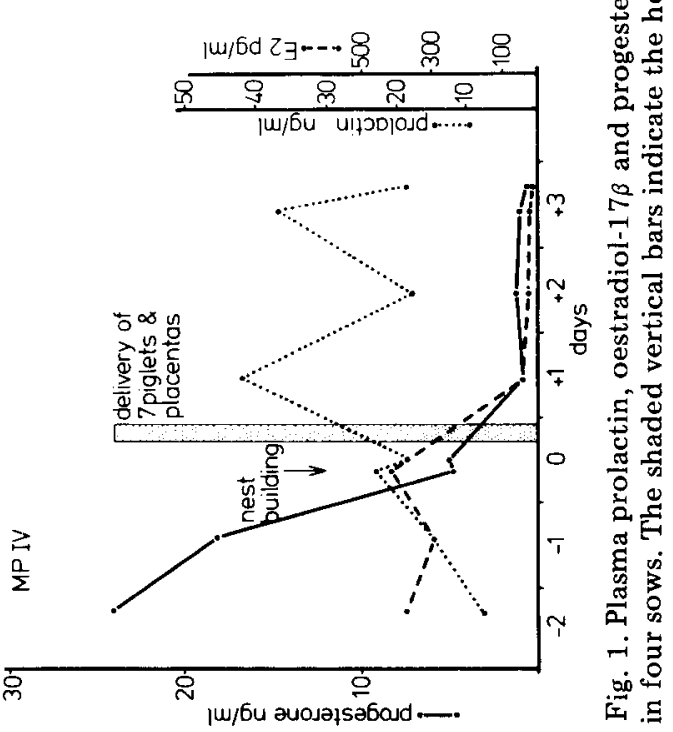


change until 1 day before parturition (no. VIII). Oestradiol concentrations showed a small increase (nos. V and 2.78) or remained constant (no. VIII) during this period.

In the three animals that were sampled more frequently during the last $40 \mathrm{~h}$ of pregnancy, a distinct increase of prolactin concentrations coincided with a decrease of the progesterone levels (Fig. 2). Maximal PRL values of

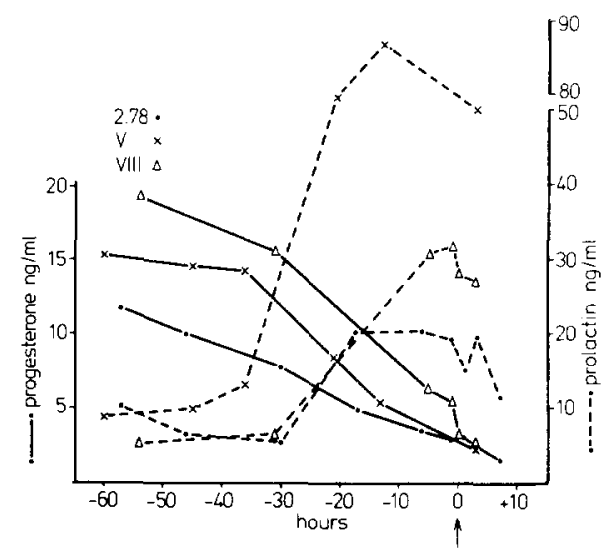

Fig. 2. Plasma prolactin and progesterone concentrations during the last $60 \mathrm{~h}$ of pregnancy in three sows. The arrow indicates the hour during which the first piglet was born.

86.7 (no. V), 32.0 (no. VIII) and $20.3 \mathrm{ng} / \mathrm{ml}$ (no. 2.78 ) were measured in samples taken at $-13,-1$ and $-17 \mathrm{~h}$ respectively $(0 \mathrm{~h}=$ delivery of the first piglet).

Maximal plasma E2 $\beta$ concentrations were found just before or during delivery of the piglets and values declined in all sows during expulsion of the placentas, reaching levels below or just above the sensitivity limit of the assay on the first day post partum (Fig. 1).

In sow no. IV that was sampled only daily, a maximal prolactin concentration of $42.0 \mathrm{ng} / \mathrm{ml}$ was measured on the first day after parturition. At this time the levels in the other three animals had either decreased (no. 2.78 ) or were still elevated (nos. V and VIII, Fig. 1).

In sow no. XI the plasma prolactin concentration increased from $8.5 \mathrm{ng} / \mathrm{ml}$ just before to $54.7 \mathrm{ng} / \mathrm{ml}$ at $1 \mathrm{~h}$ after intramuscular injection of $10 \mathrm{mg}$ prostaglandin F $2 \alpha$ on Day 110 of pregnancy (Fig. 3 ). The plasma progesterone concentration was only slightly elevated in samples taken at 1 and $3 \mathrm{~h}$ after injection but showed a sharp decrease between 6 and $8 \mathrm{~h}$ after application of the drug. During the following hours a more gradual decrease of the $\mathrm{P} 4$ levels coincided with a second elevation of the plasma prolactin concentrations. Plasma E2 $\beta$ levels remained fairly constant after prostaglandin injection until a maximal concentration of $0.44 \mathrm{ng} / \mathrm{ml}$ was measured $26 \mathrm{~h}$ later, i.e. one hour before delivery of the first piglet. 


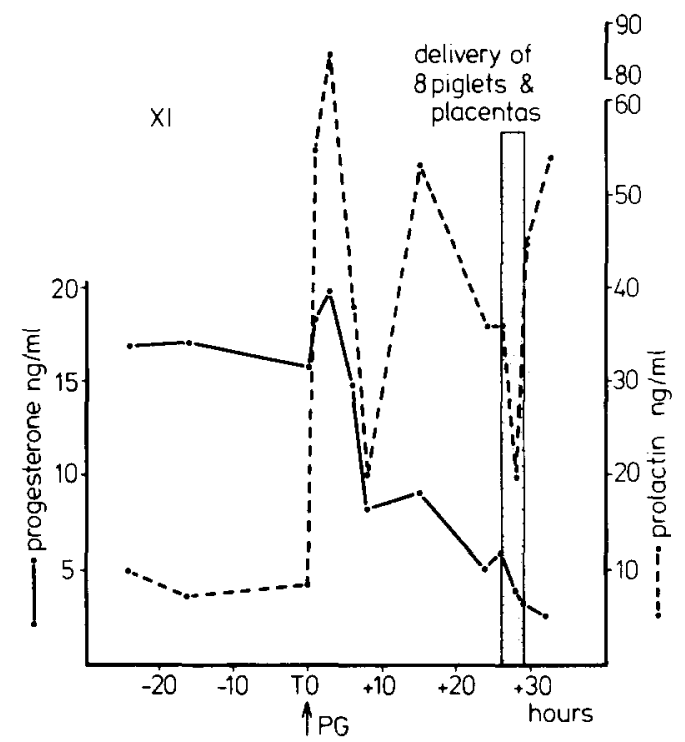

Fig. 3. Plasma prolactin and progesterone concentrations before and after intrasmuscular injection (TO) of $10 \mathrm{mg}$ prostaglandin F $2 \alpha$ on Day 110 of pregnancy in sow no. XI. The shaded vertical bar indicates the hours during which delivery of eight piglets and placentas took place.

\section{DISCUSSION}

The peripheral plasma progesterone and oestradiol-17 $\beta$ concentrations found in this study closely resemble those reported by Robertson and King (1974), Ash and Heap (1975) and Fèvre et al. (1975) and indicate that spontaneous parturition occurs after a change in their ratio.

The basal concentrations of prolactin during late pregnancy, as measured in this study, provide a limited picture of the release of this hormone because sampling took place only daily and therefore specific fluctuations may have been missed. The gradual increase of prolactin values during the last 2 weeks of pregnancy, as observed in two sows, needs further investigation with a more appropriate sampling schedule.

An increase of plasma prolactin concentrations, coinciding with a decline of progesterone levels before parturition, has also been reported in the dog (Gräf, 1978), cow (Hoffmann et al., 1973) and sheep (Kann et al., 1978). However, the increase of prolactin levels in the cow does not seem to play an important role in the initiation of parturition as inhibition of prolactin release by 2 -Br- $\alpha$-Ergocryptin did not prevent spontaneous parturition (Schams, 1974). In addition, the same treatment in sheep did not anticipate the induction of premature parturition with dexamethasone (Burd et al., 1978). With the data now available for the sow it is still impossible to detect any causal relationship between the changes in plasma 
progesterone and prolactin concentrations. A pregnancy-terminating mediation of prolactin is suggested by Gräf (1978) for the dog. By contrast, Kann et al. (1978) demonstrated that progesterone rather than oestrogens regulates prolactin release in the pregnant sheep. The concurrent changes in prolactin and progesterone concentrations in the absence of any change of the E2 $\beta$ levels, as reported in this study, suggest that the same may be true for the sow.

The high prolactin and lowered progesterone concentrations that were measured in samples taken several hours before the onset of delivery may be related to the induction of nest-building behaviour which was observed in all sows at early stages of parturition.

The change of plasma progesterone concentrations after injection of $10 \mathrm{mg}$ PG F $2 \alpha$ in the sow on Day 110 of pregnancy is similar to that reported by Wetteman et al. (1977), who used a similar dose of the same drug in gilts on Day 108 of gestation. The present experiment shows that there is a dramatic increase in the prolactin concentration during the first hours after intramuscular injection of prostaglandin $\mathrm{F} 2 \alpha$. A comparable increase of plasma PRL levels has been reported after intramuscular injection of PG F $2 \alpha$ in dioestrous heifers (Louis et al., 1974) and after administration of this drug via the transcervical route in the second trimester of pregnancy in women (Yue et al., 1974). Prostaglandins may therefore be used in sows with agalactia due to inadequate PRL support.

The second increase of the prolactin concentrations around prostaglandininduced delivery may be related to the decreased progesterone levels at this time, as was suggested in the sows with a spontaneous onset of parturition.

\section{ACKNOWLEDGEMENTS}

The authors wish to thank Ms. Th. Blankenstein, Ms. R. van Oord, Dr. P. Fontijne and Dr. G.C. van der Weyden for technical assistance.

\section{REFERENCES}

Ash, R.W. and Heap, R.B., 1975. Oestrogen, progesterone and corticosteroid concentrations in peripheral plasma of sows during pregnancy, parturition, lactation and after weaning. J. Endocrinol., 64: 141-154.

Bevers, M.M., Willemse, A.H. and Kruip, Th., 1978. Plasma prolactin levels in the sow during lactation and the post weaning period as measured by radioimmunoassay. Biol. Reprod., 19: 628-634.

Bontekoe, E.H.M., Blacquiere, J.F., Naaktgeboren, C., Dieleman, S.J. and Willems, P.P.M., 1977. Influence of environmental disturbances on uterine motility during pregnancy and parturition in rabbit and sheep. Behav. Processes, 2: 41-73.

Burd, L.I., Ascherman, G., Dowers, S., Scommegna, A. and Auletta, F.J., 1978. The effect of 2 -Br- $\alpha$-Ergocryptine on mammary blood flow and endocrine changes at the time of parturition in the ewe. Endocrinology, 102: 1223-1229. 
Chamley, W.A., Buckmaster, J.M., Cerini, M.E., Cumming, I.A., Goding, J.R., Obst, J.M., Williams, A. and Winfield, C., 1973. Changes in the levels of progesterone, corticosteroids, estradiol-17 $\beta$, luteinizing hormone and prolactin in the peripheral plasma of the ewe during late pregnancy and at parturition. Biol. Reprod., 9: 3035 .

De Jong, F.H., Baird, D.I. and Van der Molen, 1974. Ovarian secretion rates of oestrogens, androgens and progesterone in normal women and in women with persistent ovarian follicles. Acta Endocrinol (Copenhagen), 77: 575-587.

Ellendorff, F., Parvizi, N., Elsaesser, F. and Smidt, D., 1977. The miniature pig as an animal model in endocrine and neuroendocrine studies of reproduction. Lab. Anim. Sci., 27: $822-830$.

Fèvre, J., Terqui, M. and Bosc, M.J., 1975. Mécanismes de la naissance chez la truie. Equilibres hormonaux avant et pendant le part. J. Rech. Proc. France, Febr. 1975, serie X, pp. 393-397.

Gräf, K.J., 1978. Serum oestrogen, progesterone and prolactin concentrations in cyclic, pregnant and lactating beagle dogs. J. Reprod. Fertil., 52: 9-14.

Hart, I.C., 1972. A solid phase radioimmunoassay for ovine and caprine prolactin using sepharose 6B: its application to the measurements of circulating levels of prolactin before and during parturition in the goat. J. Endocrinol., 55: 51-62.

Hoffmann, B., Schams, D., Giminez, T., Ender, M.L., Herrmann, Ch. and Karg, H., 1973. Changes of progesterone, total oestrogens, corticosteroids, prolactin and LH in bovine peripheral plasma around parturition with special reference to the effect of exogenous corticosteroids and prolactin inhibitor respectively. Acta Endocrinol. (Copenhagen), 73: 385-395.

Kann, G. and Denamur, R., 1974. Possible role of prolactin during the oestrous cycle and gestation in the ewe. J. Reprod. Fertil., 39: 473-483.

Kann, G., Carpentier, M.C., Fèvre, J., Martinet, J., Maubon, M., Meusnier, Ch., Paly, J. and Vermeire, N., 1978. Lactation in sheep, role of prolactin in initiation of milk secretion. In: C. Robijn and M. Harter (Editors), Progress in Prolactin Physiology and Pathology. Elsevier/North Holland/Biomedical Press, Amsterdam, pp. 201-212.

Karg, H. and Schams, D., 1974. Prolactin release in cattle. J. Reprod. Fertil., 39: 463472.

Louis, T.M., Stellflug, J.N., Tucker, H.A. and Hafs, H.D., 1974. Plasma prolactin, growth hormone, luteinizing hormone and glucocorticoids after prostaglandin F $2 \alpha$ in heifers. Proc. Soc. Exp. Biol. Med., 147: 128-133.

Robertson, H.A. and King, G.J., 1974. Plasma concentrations of progesterone, oestrone, oestradiol $-17 \beta$ and of oestrone sulphate in the pig at implantation, during pregnancy and at parturition. J. Reprod. Fertil., 40: 133-141.

Schams, D., 1974. Untersuchungen über Prolaktin beim Rind. Advances in Animal Physiology and Animal Nutrition, Heft 5. Verlag Paul Parey, Hamburg, Berlin, 125 pp.

Taverne, M.A.M., Van der Weyden, G.C., Fontijne, P., Ellendorff, F., Naaktgeboren, C. and Smidt, D., 1977. Uterine position and presentation of minipig fetuses and their order and presentation at birth. Am. J. Vet. Res., 38: 1761-1764.

Threlfall, W.R., Dale, H.E. and Martin, C.E., 1974. Porcine blood and hypophyseal prolactin values. Am. J. Vet. Res., 35: 1491-1493.

Van Landeghem, A.A.J. and Van de Wiel, D.F.M., 1978. Radioimmunoassay for porcine prolactin: plasma levels during lactation, suckling and weaning and after TRH administration. Acta Endocrinol. (Copenhagen), 88: 653-667.

Wetteman, R.P., Hallford, D.M., Kreider, D.L. and Turman, E.J., 1977. Influence of prostaglandin $\mathrm{F} 2 \alpha$ on endocrine changes at parturition in gilts. J. Anim. Sci., 44: 106-111.

Yue, D.K., Smith, I.D., Turtle, J.R. and Shearman, R.P., 1974. Effect of prostaglandin F $2 \alpha$ on the secretion of human prolactin. Prostaglandins, 8: 387-395. 